\title{
POSSIBLE GREAT BLACK-BACKED GULL IN SASKATCHEWAN
}

STAN SHADICK, 3F-1800 Main St., Saskatoon, Saskatchewan. S7H 4B3

On the afternoon of 9 May 1983, Lawrence Baschak and I were returning home from a camping trip in the proposed Grasslands National Park. Upon reaching Blackstrap Lake (about $40 \mathrm{~km}$ se of Saskatoon, Saskatchewan) we decided to stop and search for Greater Scaup which had been seen a week earlier.

As we were scanning several flocks of scaup on the lake, a tremendously large gull flew past at a distance of about $100 \mathrm{~m}$. The wingspan appeared much larger than my recollection for that of a Herring Gull. The gull was in immature plumage with a broad dark terminal tail-band that contrasted with a light-coloured base to the tail and pale underparts. The tail-band was wider than that in immature Ring-billed Gulls. The wingtips appeared darker than the rest of the wing.

Plate 40 in Tuck illustrates typical immature plumages of flying Herring, Glaucous, Ring-billed, Lesser Blackbacked and Great Black-backed Gulls. ${ }^{4}$ The Blackstrap bird most closely resembled the illustration of a Great Black-backed Gull.

In my opinion, the large size of this gull eliminates the possibility of its being a similarly plumaged California, Herring or Lesser Black-backed Gull. Average gull wingspans are: Ringbilled, $122 \mathrm{~cm}$; California, $125 \mathrm{~cm}$; Lesser Black-backed, $127 \mathrm{~cm}$; Herring, $132 \mathrm{~cm}$; Glaucous, $135 \mathrm{~cm}$; Greater Black-backed, $165 \mathrm{~cm} .{ }^{4}$ A Great Blackbacked Gull has therefore a wingspan
$33 \mathrm{~cm}(25 \%)$ greater than a Herring Gull - a difference that should be apparent to an observer familiar with Herring Gulls. The broad terminal tailband rules out either Glaucous or Ringbilled Gulls.

Although there had been a strong north wind all day with gusts in excess of $60 \mathrm{~km} / \mathrm{h}$, the gull showed little difficulty in flying into the wind. It then began to attack a flock of scaup causing them to disperse in all directions. I have previously witnessed such behaviour only in two Glaucous Gulls which visited Saskatoon in January 1983. However, this behaviour has been reported in Great Black-backed Gulls. ${ }^{3}$ Moreover, the Smithsonian Identification Manual describes the Great Black-backed Gull to be "much more rapacious and predatory" than the Herring Gull. ${ }^{5}$

The question arises as to how a Great Black-backed Gull, which has never been reported in Saskatchewan, should come to Blackstrap Lake. Range maps in the new Peterson field guide show that it winters in the Great Lakes as far west as Lake Michigan. ${ }^{2}$ During late May and June it is a rare visitor to Churchill, Manitoba. In fact, in June 1982, the SNHS Churchill Tour observed an immature Great Blackbacked Gull near the motel where we stayed. I would suggest that the Blackstrap bird may have been migrating from the Great Lakes to Hudson Bay and was blown off course by the strong winds of 9 May 1983. 
I wish to thank Stuart Houston and Bernie Gollop for reviewing this note.

1 LANE, J., and CHARTIER, B. 1983. A birder's guide to Churchill. L \& P Press, Denver.

2 PETERSON, R. T. 1980. A field guide to the birds east of the Rockies. Houghton Mifflin Co., New York.
3 STOKER, T, 1968. Birds of the Atlantic Ocean. Hamlyn House, Feltham, England.

4 TUCK, G. 1978. A field guide to the seabirds of Britain and the world. Collins, London.

5 WATSON, G. 1966. Seabirds of the tropical Atlantic Ocean. Smithsonian Press, Washington.

\section{NESTING ROSE-BREASTED GROSBEAKS}

JEAN BANCROFT, 306-200 Tuxedo Ave., Winnipeg, Manitoba. R3P OR3.

For the past few summers I have observed nests of the Rose-breasted Grosbeak at Whytewold on Lake Winnipeg. In the spring of 1983 a pair of these birds visited our feeder frequently, and eventually a nest was built for the first time on our property.

A male and female came to the feeding tray on 28 May. The fact that these birds continued to appear at the feeder for many days indicated to me that they might be planning to build their nest somewhere close by. It was not until 16 June, however, that I finally discovered the nest. I saw and heard the male singing its soft sweet song from a high branch of a tall oak in our wooded lot. The nest was in a nearby Saskatoon bush. It was approximately $1.8 \mathrm{~m}$ from the ground; the female was sitting. The nest site was surrounded by a thicket of hazelnut. When I made my observations I had to be cautious so as not to disturb these secretive birds.

Unfortunately I did not see the nest being built. Bent states that both male and female take part in its construction; ${ }^{2}$ another authority says the nest is built by the female. ${ }^{5}$ This nest was firmly but loosely built of slender twigs from the hazelnut bushes, and was lined with fine rootlets. I examined the nest after the young fledged and found it true that I could see through it from below. ${ }^{2}$ I could not determine the size of the clutch which varies from 3 to $5 .^{2}$

Several occasions on 17 June I observed the female sitting. In late afternoon the male gave his "tick" call, the female flew up to a high branch on an adjacent tree, and the male gave her a sunflower seed (from our feeder); then he flew down and sat on the nest. She flew away for a respite. Both the male and female incubate. The incubation period is cited as being from 12 to 14 days. ${ }^{5}$

I found it very interesting to watch how both parents shared their duties. The "tick" call was the signal for one or the other to take a turn on the nest; 